Marta Postuła

Kozminski University

\title{
MULTIANNUAL BUDGETARY FRAMEWORKS - POLISH EXPERIENCES
}

\section{Introduction}

According to the conclusions resulting from the review of the quality of public finances carried out by the $\mathrm{OECD}^{1}$, the introduction of medium-term perspective in budgetary planning enhances the ability of the government, the Ministry of Finance in particular, to design and maintain a sustainable fiscal path. Activities (public interventions) that are implemented by the public sector are in most cases of a multiannual nature. Strategies and development programs, including public investments and the process to consolidate and restructure public finances, are of multiannual character. The effects of activities and their physical results are often delayed in time from the moment of their planning and rarely close during a single fiscal year.

The EU Council Directive on requirements for budgetary frameworks of the Member States (hereinafter: the Directive) imposes an obligation ${ }^{2}$ to base budget planning on a credible and effective medium-term budgetary framework with at least a three-year perspective. In compliance to the Directive, the mediumterm framework includes multiannual targets for deficit and debt, expenditure and revenue forecasts, description of activities, as well as the assessment of impact of the adopted medium-term framework for multiannual stability of public finances. Every subsequent annual budget law should be consistent with the medium-term budgetary framework. The gist of this approach can be found in the actions taken by individual countries around the world. According to the data available at the end of 2012, some Budget Institutions In OECD Countries Results Of The 2012 OECD Budget Practices And Procedures Survey. Draft, Paris, May 2013.

2 Art. 9 of the EU Council Directive 2011/85/EU of 8 November 2011 on requirements for budgetary framework of member states, Official Journal of the European Union of 23 November 2011, L 306/41. 
27 OECD countries were using the medium-term perspective ${ }^{3}$ in their budgetary planning. In 2007, this practice was applied by only 19 countries, which means a significant increase in the use of multiannual planning for financial management. In most countries, the adopted medium-term planning horizon is between 3-4 years (see Figure 1).

Figure 1. Planning Horizon in OECD Countries

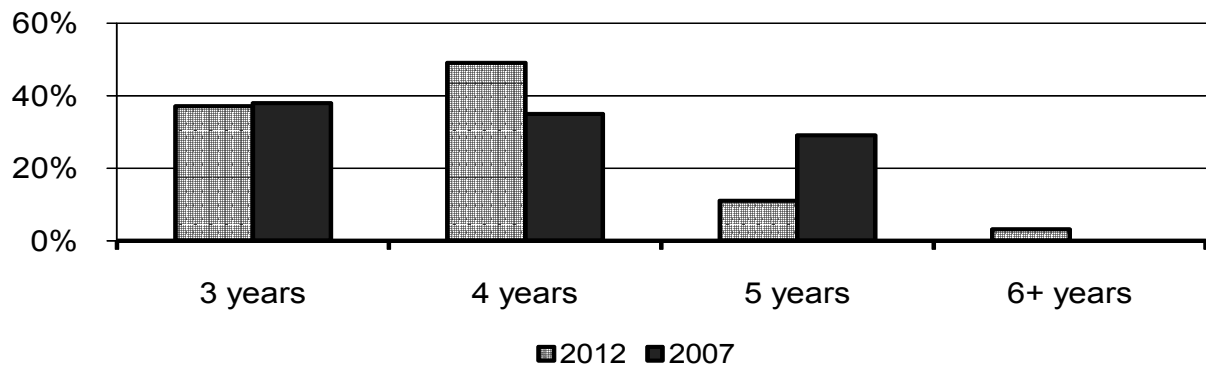

Source: Own calculations based on OECD data.

The OECD survey results indicate that the medium-term forecasts and plans are usually updated annually. Only in six countries, are the medium-term plans not updated every year, but rather every 2-3 years. The scope and complexity of medium-term plans in individual countries is each and every time linked to their past experiences in medium-term forecasting. The success and effectiveness of the procedures used are primarily associated with the maintenance of a balance between improving the predictability and the relevant flexibility. In most cases, the key component of the medium-term plan are forecasted expenditures, including the socalled mandatory, or fixed and flexible.

The reasoning behind opting for an annual update of the medium-term plans is the fact that they are used as the foundation for the annual budget law. At the same time, sufficient flexibility is maintained to allow for the possibility of annual adjustment to meet changing internal and external conditions. The annual frequency of updates also allows for an adequate response in case priorities change as a result of parliamentary elections, as well as helping to reduce the negative effects of the so-called budgetary games (e.g. starting up costly investment projects using scarce funding in the current annual budget). All changes to the plans and budgetary forecasts, regardless of their cause, shall be made while maintaining the mediumterm perspective. 
According to the OECD report, this is mostly the job of the executive power in some 27 OECD countries using medium-term planning. Only in 10 countries, are the medium-term plans approved by parliament. The OECD ${ }^{4}$ study specified the medium-term budget planning rules that determine the success of these processes. These factors are as follows: conservative planning of expenditures and incomes, providing support to spending cuts, complexity of plan strengthening its credibility, simplicity allowing for the plan to be understood by the citizens and legislative authorities, consistency with development strategies, transparency of annual changes in expenditures in relation to previous plans.

\section{Polish experience in multiannual planning}

Under the task-based system, which has been introduced by the government administration in Poland since 2007, a multiannual planning perspective is developed in the state budget. As in other countries, the process to implement such planning is complex and lengthy by nature. In 2009, changes were made to the public finances legislation which resulted in the full functionality of the multiannual task-planning system.

To a large extent, it is the aforementioned arguments that the draft budget initiators and the legislator had in mind when introducing in the Public Finance Act $^{5}$ of 27 August 2009, detailed solutions for multiannual planning both at the central level - the State Multiannual Financial Plan (SMFP) - and at the local level - Multiannual Financial Forecast (MFF).

The State Multiannual Financial Plan is the foundation of medium-term budgetary planning at the government level. It was introduced following a careful analysis of such tools operating in other countries. The Polish model of multiannual planning is very similar to the model that has for many years been successfully used in Finland. ${ }^{6}$

Creation of SMFP was possible by using the experiences gained in mediumterm planning and task-based budgeting methodology which has had largely presentational character so far. The Public Finance Act envisages that SMFP is developed and adopted by the Council of Ministers by resolution. The mode and the rules for drafting SMFP preserve the new quality of multiannual planning in the public administration, associated with the use of the latest methods of public finance management. The fundamental and at the same time pioneering component of the

$4 \quad$ Working Party of Senior Budget Officials, $34^{\text {th }}$ Annual Meeting of OECD Senior Budget Officials, Strengthening Budget Institutions In OECD Countries Results Of The 2012 OECD Budget Practices And Procedures Survey. Draft, Paris, May 2013.

5 Act of 27 August 2009 on public finance, Official Journal of 2009. No. 157, item 1240, as amended.

6 In Finland, a four-year budgetary plan is developed with objectives assigned for individual budget tasks and with resources dedicated to them. The plan, prepared by the Finance Minister, is adopted by the government. The parlament discusses the plan that has been prepared, however, it does not make any binding decisions about it. 
plan, is the state budget expenditure forecast that is drawn up in the state functions system, including the definition of objectives and measuring indicators showing the degree of their implementation.

The first State Multiannual Financial Plan for the years 2010-2013 was adopted by the Council of Ministers on August $4^{\text {th }}, 2010 . .^{7}$ In accordance with the Public Finance Act provisions, the SMFP stands for the plan of incomes and expenses as well as revenues and expenditures of the state budget for four years. The SMFP is compiled on a task-basis involving the functions of the state, along with the objectives and indicators measuring the degree of implementation of a given function. The document recognizes the objectives of the medium-term national development strategy, as well as the directions of socio-economic policy in a given period. Thanks to the task-based system, SMFP stimulates higher efficiency of the management and disbursement of public funds, and credibility, transparency and predictability of fiscal policy, in particular by linking state budget expenditure with the mediumterm and multiannual priorities of the government. Reporting on the implementation of the State Multiannual Financial Plan includes measuring the effects of activities performed by public institutions, which allows to assess the level up to which assumed objectives have been achieved. SMFP, using the medium-term perspective, helps optimize decisions to allocate total public expenditures and increase the sustainability of public finances. Subsequent SMFP were the basis to work on the budget laws for 2011-2014, especially in terms of the task-based presentation of state budget expenditures and the state budget deficit.

In accordance with the statutory rules, an update of SMFP is prepared annually for the current financial year and the three subsequent financial years. Also, until May $30^{\text {th }}$ of each year, information shall be drawn up about the progress of the SMFP execution as adopted by the government the year before. An analysis of the relevant documents has been presented in the next section of this chapter already on the basis of these three documents relating to the multiannual planning (for the first time during the socio-economic transformation), regulated by legislation.

Appreciating the beneficial nature of multiannual planning, it has also been applied at local government level where relevant tools have been introduced, i.e. the Multiannual Financial Forecast (MFF), which is a tool for multiannual planning for use by local government units. MFF is adopted by resolution of the legislative body and cannot be drawn up for a period of less than one financial year and the three subsequent years. Debt forecast for the entire period of its maturity is part of MFF, i.e. until the final deadline for repayment of liabilities incurred by a given local government unit. MFF is the stepping projection that is supplemented (extended) for years 2012-2015 (8 May 2012), SMFP for years 2013-2016 (30 April 2013). 
the next financial year, so that it would cover each financial year and at least three consecutive years.

The Multiannual Financial Forecast (MFF) includes a projection of inter alia such parameters of the local government budgetary units as:

- budget incomes in breakdown to incomes and current expenses, including for debt servicing, guarantees and sureties;

- incomes and material expenditures, including incomes from the sale of assets;

- budget result;

- revenues and expenditures of the budget, including debt incurred and planned to be incurred.

MFF also includes the debt amount forecast and the authorizations for an executive body of the local government unit to make commitments under such agreements of which the implementation is essential in the financial year and in the subsequent years, to ensure the continuity of the local government unit operation and the payments that fall in subsequent years. The Appendix to MFF defines the limits of spending and commitments for multiannual undertakings (multiannual programs, projects or tasks). Just as in the case of the budget resolution, the initiative on the preparation and submission for adoption of the draft resolution on the multiannual financial forecast and its amendments, should be addressed only to the management board of the local government unit.

\section{Multiannual Planning Activities in Poland in 2012-2013}

Despite the implementation of the medium-term planning mechanisms into the Polish legislation system, EU regulations enforce their improvement and consistency of appropriate solutions with other EU countries. The deadline for the enforcement of solutions - called for in the Directive on requirements for budgetary frameworks of the EU Member States - into the national legislation expires at the end of 2013. The actions to be taken by the Member States in this matter shall therefore be performed within a little more than two years. The scope of the required supplementations to the national legislation, related to the multiannual planning horizon, was moderate in the case of Poland. The solutions discussed earlier and included in the Public Finance Act of 2009, although made ex ante, largely exhaust the requirements of the Directive in the area discussed hereto.

In December 2012, one year following publication of the Directive, a law was adopted amending certain acts due to the implementation of the budget law ${ }^{8}$. 
Article 8 of this Act, recognized the latest package of amendments to the multiannual budgetary planning. A rule was preserved that the primary way of presenting state budget expenditure in the multiannual plan is to break it down into the functions of the state, along with an indication of objectives and measuring indicators (the additional method of expenditure disaggregation, originally introduced in 2009, was abandoned). In place of a floating date, to be determined by the government, to adopt SMFP (two months after the publication of the Budget Act), a specific deadline was introduced (April $30^{\text {th }}$ of each year). This clarification improves coordination of works to prepare various government documents (e.g. subsequent updates of the convergence programs) in the areas of planning and forecasting the public finances. In addition, the selected date is consistent with the schedule of the European Semester for economic policy coordination ${ }^{9}$ introduced in 2011, as part of the update of the EU Stability and Growth Pact. Another amendment, clarifying the scope of forecasts in SMFP, was to include under this plan a consolidated plan of budget spending for the financial year and three consecutive years of state budgetary units, executive agencies, budgetary economic institutions, state target funds, and state legal persons (other state or local government legal entities established on the basis of separate acts to perform public tasks, except for companies, research institutes, banks, and commercial partnerships).

New solutions related to MFF created a system of reliable flow of information on the status and the medium-term financial plans of local government units towards the Finance Minister. Also Important, was a commitment for the Finance Minister to issue the Regulation on MFF specimen and the procedure on the flow of information from these units to Regional Accounting Chambers (RIOs) and thence to the Finance Minister. The purpose of the MFF-related amendments was to ensure:

- openness and transparency of public finances;

- preparation of realistic financial projections of local government units;

- for the Finance Minister to obtain information allowing the level of debt and the deficit of the entire public finance sector to be controlled.

The obligation to include under the SMFP the consolidated financial plans of specified public finance sector entities as well as the system of information flow from the local government subsector to the Finance Minister, improves the quality of monitoring the financial standing in the entire sector of central and local government institutions as well as the credibility of plans, and also forecasts prepared by the sector as a whole. The unified and comprehensive multiannual budgetary planning procedures have thus been extended to the whole sector of central and local

9 Art. 1 section 3 of the Regulation by the EUropean Parliament and the Council (UE) No. 1175/2011 of 16 November 2011 amending the Regulation by the Council Regulation (EC) No 1466/97 on the strengthening of the surveillance of budgetary positions and the surveillance and coordination of economic policies, Official Journal of the European Union of 23 November 2011, L 306/12. 
government institutions. The forecasting data will be obtained in a more realistic and effective way from the local government subsector, which should mitigate the risk of inappropriateness and errors of these forecasts. This solution meets, under Article 13 of the Directive, the postulate of a comprehensive and consistent account of all sub-sectors of the central and local government institutions in the general budget planning.

Item 20 of the preamble to the Directive, clearly states that the basis for planning of the annually adopted budget law should be multiannual budget planning. This provision is in line with the binding in Polish law since 2010, Article 105 section 1, which shows that SMFP is the basis for the preparation of a draft budget law for the next financial year. Analysis of the hitherto scope of the SMFP content, indicates that despite its clear indication as the basis for annual planning, it does not exhaust all provisions of the Directive.

According to the provisions of the Directive, medium-term budgetary framework should include procedures to prepare inter alia such comprehensive and transparent budgetary targets on debt and deficit, and other summary fiscal indicators (especially expenses), forecasts of major expenditures and incomes, courses of action to achieve the medium-term objectives and to assess their impact on the long-term stability of public finances.

A comprehensive overview of the key multiannual budgetary planning documents in Poland (SMFP, MFF, Convergence Program Updates (APK), public debt management strategies) allows to say that recommendations for a mediumterm framework have largely been met. Forecasts of incomes and expenditures are prepared, there are analyses and assessments of the consequences of actions to achieve deficit and debt-related objectives, and there are annually updated deficit and debt-related objectives based on realistic macroeconomic assumptions. A deficiency of the current system is, however, a limitation of the basic scope of financial forecasts in SMFP to the state budget, with only point-based inclusion of debt and deficit forecasts for the entire central and local government institutions. Dispersion of information and medium-term forecasts in various documents reduces the transparency of the entire system, although the level of the planning and forecasting coordination already seems to be at least satisfactory.

Although the Directive does not contain a postulate to develop a single comprehensive medium-term planning document, a subsequent package of the proposed amendments (concerning SMFP scope) to the Public Finance Act has been prepared in Poland in 2013. According to the new SMFP law, it will contain a forecast of incomes and expenditures of central and local government as well as macroeconomic forecast, and it is to respect the directions, guidelines, and recommendations issued under the multilateral surveillance procedures framework in the EU. The two main components of SMFP shall constitute a convergence program (or rather its update) and forecast of expenditures by functions of the state 
and their assigned objectives, together with indicators measuring their achievement level. The prepared draft specifies an obligation to include in the SMFP content specific forecasts for the central and local government institutions sector, namely:

- level of the medium-term budgetary objective;

- priorities of government policy;

- forecasts of the main items of incomes and expenditures;

- planned activities together with an indication of their impact on the level of incomes and expenditures, as well as on the long-term stability of public finances;

- forecasts of the sector result;

- projections of public debt;

- indication of changes in the activities and objectives compared to the previous SMFP.

The scope of the proposed changes to the structure of SMFP is a proper complement to the existing legislation in order to accurately meet all the postulates of the Directive (contained mostly in its Art. 9) with respect to the rules and mode for multiannual budgetary planning in an EU member state.

\section{Summary}

Since the inception of the European Union, the EU countries have been declaring to conduct a reliable economic policy conducive to achieving stable and sustainable growth for the entire association. The proper functioning of the entire community requires an adequate level of real convergence, involving the leveling of differences in socio-economic development among individual member states, the pursuit of concurrence of business cycles, and so on. The condition of this process is that individual countries should meet nominal convergence criteria of which the important component is the fiscal criterion and the stable well-managed public finances directly associated with it.

The European Union legislation included in the treaties and regulations, and in the Stability and Growth Pact in particular, was to lead to the improvement of real convergence within the group. Analysis of the fiscal criteria of nominal convergence in the years of 1999-2012 indicates that the achievement of the PSiW assumptions and objectives was ineffective. Since 2011, there has been a significant expansion of legislation in this area, including on the so-called excessive deficit procedure. Under the framework of the new organization of multilateral surveillance and economic policy coordination, many components have been changed and the introduction of modern tools for budgetary policy management have been ordered. Some solutions remain voluntary - the key decisions on the form of how to implement individual 
solutions on the budgetary framework to the national legislation are to be made by authorities of the individual countries. As of today, it is difficult to assess the effects of regulations introduced under the budgetary framework. However, the most important, and which should be achieved thanks to them in the medium-term perspective, is the final result that refers to the level of deficit of the central and local government institutions sector of the individual EU member states. 


\section{WIELOLETNIE RAMY BUDŻETOWE - POLSKIE DOŚWIADCZENIA}

Dyrektywa Rady UE w sprawie wymogów dla ram budżetowych państw członkowskich (zwanej dalej „Dyrektywą”) nakłada obowiązek, aby podstawą planowania budżetu były wiarygodne i efektywne średnioterminowe ramy budżetowe z przynajmniej trzyletnią perspektywą. Od 2009 r. w polskiej legislacji są już regulacje dotyczące średnioterminowego planowania finansowego, zarówno na poziomie centralnym, jak i lokalnym. Dzięki temu, w 2012 r. Polska znajdowała się na 5 miejscu pod względem jakości średnioterminowego planowania wśród państw członkowskich OECD. Potrzeba wdrożenia Dyrektywy wymaga wprowadzenia jedynie zmian doprecyzowujących obecnie obowiązujące regulacje średnioterminowego planowania.

Słowa kluczowe: Wieloletni Plan Finansowy Państwa, deficyt budżetowy, średnioterminowe cele budżetowe

Keywords: State Multiannual Financial Plan, budget deficit, medium-term budgetary objective 